\title{
THE "CAPITAL ASSET" CONCEPT: A CRITIQUE OF CAPITAL GAINS TAXATION: II*
}

\author{
PETER MILLER广்
}

THE capital gains provisions of the Internal Revenue Code presume: (1) that "investment" gains can be satisfactorily distinguished from "business" and "speculative" profits, and (2) that "investment" gains deserve favored treatment. Part I of this article has demonstrated that in practice the attempted segregation of investment gains has been unsuccessful. The following discussion evaluates the principal arguments put forward in support of the thesis that investment gains should be taxed more leniently than income received in other forms.

\section{The Rationale of the Capital Gains Provisions- Why the LaW SeEts to Favor "Investarent"}

The special treatment accorded to "investment" gains is usually supported by two types of argument. One asserts that to apply ordinary surtax rates to such gains would be inequitable. The other claims that to do this would impede the efficient operation of the national economy. ${ }^{1}$

\section{A. Arguments Concerning Fairness}

The first type of argument seeks to establish the proposition that capital gains do not represent an increase in ability to pay comparable to that represented by an equal amount of "ordinary income" and that therefore it is unfair to tax capital gains to the same extent.

\section{Taxing Several Years' Gains in One}

According to one line of argument, a profit realized upon the sale of property which has gradually ${ }^{2}$ appreciated in value over a period of

* Part I of this article appears at 59 Y ALE L.J. 837 (1950).

$\div$ Member of the New York Bar.

1. Both of these lines of thought are implicit in the Report of the House Ways and Means Committee which recommended the enactment of the initial capital gain provisions in 1921 : "The sale of farms, mineral properties, and other capital assets is now seriously retarded by the fact that gains and profits earned over a series of years are under the present Faw taxed as a lump sum in the year in which the profit is realized. Mlany such sales, with their possible profit-taking and consequent increase in the tax revenue, have been blocked by this feature of the present law." H.R. REP. No. 350, PART 1, 67th Cong., 1st Sess. 10-11 (1921). Despite perennial re-examination of the capital gains provisions, this elliptical utterance remains the authoritative statement as to their justification.

2. Although most commentators assume for illustrative simplicity that gains and losses accrue gradually over the holding period, in many factual situations this is obviously not so. Where the market value of a capital asset remains at cost for ten years and then undergoes a sharp increase or decrease which induces its sale, it is hard to see why the gain or 
more than one year is properly attributable, in part, to each of the years during which it accrued. Accordingly, the inclusion of the full amount of such a profit with the seller's other income for the year of the sale would give an artificially inflated measure of the change in the seller's economic well-being during that year. ${ }^{3}$ Because "ordinary income" is subject to progressive surtax rates, "cashing in" on several years' profits would result in a substantially higher tax than if a tax had been paid each year on the unrealized appreciation in value as it accrued. ${ }^{4}$ It is therefore deemed unfair to tax capital gains at graduated rates.

As has already been indicated in Part $I,{ }^{5}$ this argument is no longer valid because favorable treatment is now accorded to capital gains accruing over only six months and one day. ${ }^{6}$ However, even during the period from 1922 to $1942^{7}$ when the minimum holding period exceeded one year, a thoroughgoing application of this argument would have required mitigation of the effect of all "bunched income" -not only profit realized upon the sale of property, but also dividends, royalties, compensation for personal services, and all other types of income arising over a period longer than the taxable year. ${ }^{8}$ Nor did this policy of mitigating the tax on "bunched income" justify the distinction made between gain realized upon the sale of "business" property and that realized upon sale of an "investment." Perhaps the businessman is more likely to "turn over" stock in trade within less than one year than is the investor to resell a security within a year after its acquisition. If so, it could be argued that investors as a

loss should be treated for tax purposes as accruing evenly over the ten-year holding period. Yet the eradication of this anomaly would probably be administratively unfeasible. $C f$. Paul, Taxation for Prosperity 272 (1946).

3. The classic definition of income for tax purposes is "the money value of the net accretion of one's economic power between two points in time." Haig, The Concept of Income, c. 1 of The Federal INCOME TAX (Columbia University symposium, 1921). Cf. the definitions of taxable income in Sixions, Personal Incone Taxation 206 (1938) and HewiTt, The Definition of Income and Its Application in Federal Taxation 34 (1925).

4. "The tax on capital gains should approximate the tax which would have been paid if the gain had been realized in uniform annual amounts over the period during which the asset was held." The capital gains provisions fail to attain this objective because they "give the same relief in the case of the sale of an asset held for 2 years as they do in the case of an asset held for 20 years." Supplearental Report on Capital Gains and Losses of tile Division of Investigation of the Joint Comimitee on INTERnal Revenue Taxation, 71st Cong., 1st Sess. 2 (1929).

5. See Part I, note 23.

6. Professor Lowndes regards the shortening of the holding period as having removed "the one really meritorious argument in favor of special tax treatment for capital gains." Lowndes, The Taxation of Capital Gains and Losses under the Federal Inconte Tax, 26 TExas L. REv. 440, 442 (1948).

7. Revenue Act of 1921, $\S 206$ (a) (6), 42 Stat. 233 (1921); Revenue Act of 1938, $\S 117$ (a) (4), 52 Stat. 501 (1938).

8. See note 11 infra; cf. INT. Rev. Cone § 107. 
class have greater need for protection from the tax consequences of the piling up of accrued profits in the year of sale. This line of reasoning, however, depends not only upon a correlation between "investments" and long-accruals but also upon an identification of "capital assets" with "investments." As the preceding Sections of this discussion have indicated, the capital gain (and loss) provisions cover far more than the hypothetical "investment" of the hypothetical "investor." Therefore it does not appear that these provisions (1) merely prevent hardship when they apply, and (2) apply whenever hardship would otherwise occur. ${ }^{9}$ On the contrary it would seem that if the adjudicated cases prove anything, ${ }^{10}$ they prove that trouble will brew whenever special treatment is accorded to particular kinds of personal income. ${ }^{11}$

\section{2. "Addition to Capital" Versus "Income"}

Many types of arguments attempt to demonstrate that "capital gains" are inherently unlike the kinds of receipts that represent taxpaying ability. It has often been said that "addition to capital" is not "income" 12 - "income" having been defined so as to exclude "addition

9. This is well illustrated by the case of Carl G. Dreymann, 11 T.C. 153 (1948), wherein the Commissioner argued unsuccessfully that the capital gains provisions were intended to mitigate the hardship of taxing "the realization in one lump sum in one tasable year of an increment in value which had taken place over a number of years" and that therefore these provisions should not apply to sales proceeds received in installments continuing for several years.

10. An analysis of judicial decisions on almost any phase of the law invariably invites - the criticism that, except where facts are in dispute, most of the situations which get to the courts are aberrational rather than typical and that therefore any generalization from what the courts have done is not based upon a representative sampling. Cf. statement of Mfr. Eustace Seligman in Capital Garns Taxation 45 (Tar: Institute Symposium, 1946). According to this argument, bad cases do not necessarily indicate bad law but merely that general rules, designed to achieve salutary results in the great majority of situations, sometimes work unfairly in the unusual cases reported in judicial opinions. "What is needed is substantial justice in the majority of instances." Darrell, Recent Developments in Nonfaxable Reorganizations and Stock Dizidends, $61 \mathrm{HARv}$. L. Rev. 958, 975 (1948). Pragmatially this line of thought is dangerous; by inducing acquiescence to the legal slatus quo it dulls our awareness that the aim of the law is to do justice-even among taxpayers in borderline cases.

11. If all income were averaged over a period of years, it would not be inequitable to apply graduated surtax rates to investment gains arising over several years. Srso:ss, PETsonal Incoure Taxation 154 (1938); Vickrey, Agenda fos Peogressine Taxation 145 (1947) ; Bravman, Equalization of Tax on All Individuals arith Same Aggregate Ineome Over Same Number of Years, 50 CoL. L. Rev. 1, 23-6 (1950); Atlas, Capilal Gains Taration, 13 Accountrng Review 346, at 352, 354 (1938); DelWind, Preferred Sloek: "Bail-Outs" and the Income Tax, 62 Hanv. L. Rev. 1126, 1133 (1949). Groves, Postwar Taxation and Economic Progress 225 (1946). It should be observed, however, that " $[t]$ he present 25 per cent rate is hardly a substitute for averaging. If we had an averaging system which also covered capital gains, for many people the rates on capital gains would be over 80 per cent even though it was a rate obtained by averaging." Stanley S. Surrey in Capital Gains Taxation 47-8 (Tax Institute Symposium, 1946).

12. Although the Supreme Court long ago decided that addition to capital was cmbraced within the term "income" as used in the Sixteenth Amendment, Mferchants' Loan and Trust 
to capital." 13 Thus Professor Plehn asserts that "[i]ncome is essentially wealth available for recurrent consumption, recurrently (or periodically) received. Its three essential characteristics are : receipt, recurrence and expendability." 14 From this definition it follows that "gains and profits from transactions outside of one's regular vocation or line of business, like the profit from the sale of a home, ${ }^{15}$ are of doubtful income character." 16

Co. v. Smietanka, 255 U.S. 509 (1921), the dichotomy is still asserted to be a fact of economic life. Thus Mr. Elisha M. Friedman asserts : "There is no point of similarity betwecn capital gains and income except that they both are expressed in dollars and a taxpayer receives them. They are as similar as pigs and pig-iron. A tax on capital gains is a tax on capital." Memorandum in Hearings before Committee on Ways and Mcans on H.R. 635s, 77th. Cong., 2d Sess. 1656, 1663 (1942).

The specious metaphor in which income is compared to the fruit of a tree and capital gain to the growth of a tree is refuted by HEwiTT, THE Definition of INCOME AND ITS Application to Federal Taxation 27-8 (1925). The historical origin of this metaphor is dis= cussed by Seltzer, Evolution of the Special Legal Status of Gains under the Income Tax, 3 NAT. TAX J. 18 (1950).

13. This position was elaborated in great detail by the late Irving Fisher in Tre Natune of Capital and Incone (1906); The Incone Concept in tire Light of Extentence (1927) ; Double Taxation of Savings, 29 AMr. Econ. Rev. 16 (1939). Fisher's arguments are refuted by Musgrave, $A$ Further Note on the Double Taxation of Savings, 29 AM، Econ. Rev. 549 (1939) ; Simons, Personal Income Taxation 89-100, 225-31 (1938).

14. Plehn, Income as Recurrent, Consunable Receipts, 14 Aur. Econ. Rev. 1, 5 (1924), discussed in Lutz, Should Capifal Gains be Taxed as Income?, 22 Butc. Nat. TAx Ass'N 130 (1937).

15. The sale of a home is hardly typical of transactions outside of one's regular vocation or line of business. "The great bulk of capital gains realized in the United States is realized in connection with transactions entered into for profit. The sale of houses and farms which had previously been occupied or operated by their owners occasions many individual realizations of capital gains; but the great mass even of casual gains is derived from the sale of corporate securities, unimproved real estate, business properties, and other assets which had been acquired with a view to profitable investment." Report of Subcommittec, Hcarings bcfore Committee on Ways and Means on Proposed Tax Revision, 75th Cong., 3d Sess. 30 (1938).

Notwithstanding this fact, opponents of capital gains taxation have often sought to demonstrate its alleged unfairness by citing the case of the homeowner who realizes a gain upon sale of his house when obliged to move to another community, and who later finds himself unable to buy a similar house because the sales proceeds are depleted by the capital gains tax. See the discussion of price level changes below. However, this illustration indicates merely a special situation deserving special treatment. An appropriate solution would be to exempt completely the gain upon such a sale if the sales proceeds were reinvested in a new house within a reasonable period. Cf. INT. Rev. CODE $\$ 112(f)$; PavL, Taxatuon fon PROSPERTTy 273 (1946); Lowndes, The Taxation of Capital Gains and Losses Under the Federal Income Tax, 26 Texas L. Rev. 440, 455 (1948). This would also climinate the argument that it is unfair not to permit the deduction of losses incurred upon the sale of a residence because any gain realized on such a transaction is subject to tax. Cf. Nelson, The Question of Taxing Capital Gains: The Case Against Taxation, 7 LnW \& Contemp. Prou. 208, 216 (1940).

16. Plehn, supra note 14, at 10. Another variant of this argument (that capital gains should not be taxed because prudence forbids their being spent for consumption purposes) 
But is "anticipated recurrence" an appropriate criterion to apply in defining income for tax purposes?" 17 Is income "any the less potent because it happens to come in one splash rather than a regular flow"? 15 It is, of course, arguable that Professor Plehn's hypothetical reasonably prudent man in the street would not feel safe in entering into a longterm lease for a more expensive residence, merely because during the year he had realized some non-recurrent gains. But is not this example little more than a restatement of the contention that "income" should be restricted to mean only expenditures available for consumption, ${ }^{19}$ a point of view which is no more that of the arerage man than it is that of most of the economists who have considered the subject.:3

Under Professor Plehn's definition, special treatment of "investment" gains would be justified only to the extent that their recurrence is less predictable than the recurrence of "speculative" or "business" profits. Yet such a definition proves too much; rigorously applied it would exclude from income many non-recurrent receipts arising from "speculative" or "business" transactions.

\section{3. "Nècessity" of Reinvesting the Entire Sales Procceds}

Because the six-month minimum holding period is customarily justified as a means of segregating "investment" gains from "specula-

is that "the great bulk of capital gains are lost," i.c., will eventually be oftset by losses. George O. Míay in Caprtal Gains Taxation 21, 2 (Tax Institute Symposium, 1946). Thus Professor Lutz remarks: "It would shock some people to think of excluding from the income tax those who may be fortunate enough to take a profit in a luchy speculation in stocks or commodities, while continuing to tax more sober or more cautious folk on thcir salaries, rents and interest. In reply, it may be said, paraphrasing the old saying about those who live by the sword, that those who stay in the market long enough usually come out losers. In that day, they will have no benefit from their losses as an offset against their regular income." Lutz, Should Capital Gains be Taxed as Inconte?, 22 BurL. NAT. Tax Ass'x 130, 134-5 (1937). One fallacy of this argument that two wrongs make a right is that there may be little or no "regular income" to be offset by eapital losses. Furthermore, the argument fails to explain why the man who does not stay in the market long enough to "die by the sword" should pay no tax on his "lucky speculation."

17. Professor Shoup does not think so. "I have never attached much importance to the annual character of the thing taxed or its recurring nature, and am inclined simply to compare individuals year by year on changes in their economic status, whether or not it comes under annual, recurring, or extraordinary changes, just so the change in relative economic command of economic resources is real." Caprtal Gains Taxatron 79 (Tax Institute Symposium, 1946). Cf. the definitions of income in note 3 supra and Part I, note 154.

18. Groves, Trouble Spots in Taxation 65 (1948).

19. To constitute income, Plehn requires a receipt merely to be "available for recurrent consumption"; Fisher requires that it be actually consumed. See note 13 sifgra. However both would leave out of account for tax purposes receipts representing additional command over economic resources.

20. Cf. Musgrave, A Futrther Note on the Double Taxation of Sarings, 29 Axs. Eco:. Rev. 549 (1939), and Simons, Personal Incouse Taxation 89-100, 225-31 (1938). 
tive" profits, ${ }^{21}$ the present law appears to assume that there is something unique about such "investment" gains which merits special tax treatment. In support of this assumption, the argument is made that the investor who bought at 20 and sold at 30 six months later must reinvest all of his $\$ 10$ gain if the income from a second investment yielding the same rate of return is not to be smaller than that from the first investment. ${ }^{22}$ From this truism, the conclusion is drawn that the $\$ 10$ profit does not represent any increase in the investor's ability to pay and that it is unfair for the government to take up to $25 \%$ of the $\$ 10$. The validity of this argument depends, of course, on what caused the $\$ 10$ rise in price.

The rise may reflect the accumulation of undistributed corporate earnings. Because such earnings were not reported in the personal tax returns of the various stockholders, the latter have enjoyed an "accretion of economic power" ${ }^{23}$ free of progressive tax rates. ${ }^{24}$ The net yield from their investments has therefore been augmented, at least temporarily, by the use of the money which would have been paid to the Government if stockholders, like partners, ${ }^{25}$ were currently liable for tax on the full earnings of their collective enterprise. However when a stockholder disposes of his investment at a price reflecting the accumulated corporate earnings, ${ }^{26}$ a tax is levied upon the resultant capital gain. True, this tax will cause the income from the reinvested proceeds to be less than that of the original investment. However, this does not render it an arbitrary levy upon a mere change in the form of the taxpayer's investment. ${ }^{27}$ Rather it is a belated and incomplete

21. See Part I, note 24.

22. The taxpayer "in the 80 per cent bracket . . . can sell his stuff at a tax cost of 25 per cent of the gain. . . . What does he do with the proceeds, the 75 per cent he has left? He invests in income-yielding securities and still pays 80 per cent. Where does he get off ?" Professor Seltzer in Capital Gains Taxation 55 (Tax Institute Symposium, 1946). Cl.

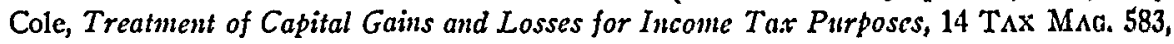
584 (1936).

23. See Professor Haig's definition of income, supra note 3.

24. Thus Justice Holmes observed: "The income tax laws do not profess to embody perfect economic theory. They ignore some things that either a theorist or a business man would take into account in determining the pecuniary condition of the taxpayer. . . . A stockholder does not pay for accumulated profits of his corporation unless he receives a dividend." Weis3 v. Weiner, 279 U.S. 333, 335 (1929).

The statement in the text is, of course, subject to qualification depending on a choice of assumptions as to (a) the shifting and incidence of the present federal corporate income tax: and (b) the relationship between the rates of that tax and the surtax rates applictible to the incomes of individual investors.

25. INT. Rev. Code $\$ 182$.

26. The price of the stock may well be less than its book value, especially where the stock: constitutes merely a minority interest. Cf. Estate of Charles W. Heppenstall, Sr., 8 T.C.M. 136 (1949).

27. "[T] he tax ... is not upon the income [i.e., the accrual of unrealized appreciation in value?] but is upon the act of the ... owner in selling. While it may be pos- 
recognition of an accrued but hitherto untaxed increase in the taxpayer's "economic power." Therefore the diminution of income on reinvestment does not, in and by itself, seem a valid reason for treating the capital gain more favorably than a dividend or other "ordinary" income.

\section{Changes in the General Price Level}

There seems little dissent from the proposition that "[t]he man who sells an asset at twice its cost but at no more in purchasing power than he paid for it, gets a truly illusory gain." ${ }^{23}$ From this the conclusion is often drawn that such gains are not a proper measure of taxpaying ability. ${ }^{29}$ This conclusion is highly questionable.

"If everyone were equally affected by the price level change the gain would be illusory. . . . [But] the gain is not illusory if some persons benefit from the change and others do not- ${ }^{2}$ if some are able to cushion the impact of the change because of the amount and character of the assets they own and can dispose of, while others are not so fortunate. ${ }^{31}$

"Should we take account of the disparity by regarding the person possessing a fixed income as having suffered a hardship, and the person who disposes of stocks at a higher price due to a change in the price level as having received no taxable gain? Or, since we do not give tax effect to the change in the position of the former group, should we [not] take account of the comparative benefit received by

sible to justify the imposition of some kind of a tax on the act of selling plus realizing the profit in money or some other form of property, it does not seem that there is any justification for treating the profit as income merely because there has been a change in the nature of the property." Cole, Treatment of Capital Gains and Losses for Income Tax Purposes, 14 TAx MAG. 583, 585 (1936).

This argument is inconsistent with that put forward by another opponent of capital gains taxation to justify the deduction of losses where the taxpayer acquires substantially similar property at the same time and at the same low price at which he makes the sale. (Cf. Iris. REv. CODE $\$ \S 23(j)$ and 118 ). "Calmiy viewed, a wash sale is as much of a decretion to economic power as any other sale, for the sale transaction is merely the registration of a decline in value that has already actually occurred." Lutz, Should Capilal Gains be Toxed as Income?, 22 BuIL. NAT. TAX Ass'N 130, 134 (1937). This argument would scem to imply that where gain rather than loss is realized, a tax is justified because there has been a registration of an increase in value that has already occurred.

28. Professor Groves in Capital Ganns Taxation 64 (Tax Institute Symposium, 1946). Cf. Professor Seltzer, id. at \&-9; Hewitr, The Definitron on Incosse Axd IIS Application in Federal Taxation 33 (1925).

29. "The dollar shifts, and if you tax capital gains a hundred per cent instead of only on that part of the capital gain which is not caused by the change in the value of the dollar, you produce a result which I think is most unfair." Eustace Seligman in Capital Garis TAXsTron 76 (Tax Institute Symposium, 1946). Cf. George O. Alay, id. at 22; Professor Carl Shoup, $i d$. at 24 .

30. Cf. Hewitr, op. cit. supra note 28, at 33. Professor Shoup in Capital Gairs TaxATron 24 (Tax Institute Symposium, 1946); Professor Seltzer, id. at 9.

31. Stanley S. Surrey, id. at 74. Cf. Paut, Taxation for Prospersty 272 (1946). 
the latter by calling it a taxable gain? ${ }^{32}$ After all, when salaries are raised in an inflationary period, we tax the increase in salary." 33

It would seem that the question "whether you get better distributive justice in taxation by completely ignoring all the gains or losses or by taxing all without making any adjustment for change in the price level" ${ }^{34}$ should be answered in favor of the latter alternative.

Under the former alternative-i.e., if "investment" gains are to be exempted because some are "inflationary" and therefore "illusory"there arises the question why the same reasoning would not also require the exemption of "speculative" and "business" gains. The answer would probably be made that "speculative" and "business" transactions are likely to be consummated more quickly than those of the "investment" type and hence do not require equal relief against substantial changes in the price level during the interval between acquisition and sale. This generalization does not seem susceptible of empirical verification. Furthermore, this argument is subject to the criticism that the statute does not, in practical operation, distinguish neatly between personifications of abstract concepts, such as "The Businessman" and "The Investor." On the contrary, the law multiplies unjustified discriminations among people engaged in essentially similar economic activities. ${ }^{35}$

\section{Changes in Interest Rates}

Somewhat parallel to the "inflation" argument is the argument against the taxation of gains resulting from a decline in interest rates:

32. Cf. Simons, Personal Incone Taxation 156 (1938) ; Professor Groves in Cap1TAL Gains Taxation 64 (Tax Institute Symposium, 1946).

33. Surrey, id. at 80 . Mr. Surrey's last statement is denied by Mr. Seligman apparently on the ground that the tax on the increase in salary is paid in depreciated dollars. I $l$. at 75 . However, it would seem that if the entire amount of the salary increase were needecl to maintain the recipient's standard of living unchanged, then the added tax would be levied on "illusory" income representing no increase in ability to pay. This also disposes of Mr. May's contention that the treatment of capital gains "stands out" among the various types of income in that no "adjustment" is made for general prices changes. Id. at 75. See also Mr. May's comment on the LIFO method of accounting for inventories, $i d$. at 23, and Professor Seltzer's reply to it, $i d$. at 76.

34. Professor Shoup in Capital Gains Taxation 24 (Tax Institute Symposium, 1946). Professor Shoup continues: "Neither is quite satisfactory, and if it were possible to include an adjustment for the price level changes, we could then tax surplus gains over and above price level changes, and somewhat as in the excess profits tax carry-back provisions, allow at deduction for a deficiency, that is, a failure to realize normal gain consistent with the change in the price level." Unfortunately segregation of gain attributable to over-all price changes, through the use of index numbers or similar devices, is probably unfeasible.

35. See, e.g., the following parallel cases discussed in Part I of this article: Brown v. Commissioner, 143 F.2d 468 (5th Cir. 1944) and United States v. Robinson, 129 F.2d 297 (5th Cir. 1942) ; Harold T. Avery, 47 B.T.A. 538 (1942) and John W. Hogg, P-H 1944 TC Mem. Dec. \ा 44,066 (1944). 
"Here is John Smith who bought $\$ 100,000$ principal amount of $4 \frac{1}{2}$ per cent bonds at par fifteen years ago. ... At the present time they would be selling on perhaps a three per cent basis. . . . If John Smith sells them, in order, let us say, to shift his funds into other bonds that he regards as safer or of more diversified maturities, he will make a capital gain of about $\$ 20,000$. . . 25

"If he pays part of that capital gain in taxes, the remaining proceeds of his bond sales will not [when reinvested] command as much interest income as he previously received." st

Here again, from the mere fact that income will be reduced after the "switching of investments," the conclusion is drawn that it is unfaireven "immoral" 38 to tax such gains. Yet, as has already been indicated, such a conclusion does not necessarily follow. One who sells an earlier investment at a profit is in a stronger position than new investors to cushion the effect of lower interest rates. "That comparative benefit may justify a tax." 39

These arguments presuppose the reinvestment of the gain. But a successful investor may, without reinvestment, live on the profit from his sale. ${ }^{40}$ As his ability to command goods and services has increased, it is not unfair to tax this increase. ${ }^{41}$ Thus here too the supposed inequity of taxing investors' gains is highly questionable.

\section{Countervailing Equitable Considerations}

With respect to each of the several arguments advanced in support of at least partial exemption of capital gains from progressive income taxes, it should be noted that there are countervailing equitable considerations in favor of the imposition of graduated rates upon capital

36. Similar in effect to a decline in the rate of bond interest is "seasoning of management," i.e., a decline in the rate at which anticipated corporate dividends are copitalized in determining stock values. "[A] company can go along earning the same amount and paying out the full amount of dividends; and as the management is successful for one year, two years, five years, or ten or twenty years, the value of the security goes up." Mr. Beardsley Ruml in Captral Gains Taxation 70 (Tax Institute Symposium, 1946).

37. Professor Seltzer, id. at 7.

38. "I think it is immoral for a government artificiolly to reduce a rate of interest and say people have made a profit out of it when actually they have suffered from it." Mir. George O. May in Capital Gains Taxation 72 (Tax Institute Symposium, 1946).

39. Stanley S. Surrey in Capital Gains Taxation 72-3 (Tax Institute Symposium, 1946).

40. To argue that this is unrealistic (because the typical investor seelis to prevent a decline in his dividends and interest by reinvesting his capital gains) is to adopt Irving Fisher's view that income is what a man spends for consumption purposes and "not what he might consume if he wanted to." Professor Shoup in Caprtal Gans Taxation 78 (Tax Institute Symposium, 1946). Cf. note 13 stipra.

41. Professor Lawrence Seltzer in Capital Garns Taxatrox 78 (Tax Institute Symposium, 1946). "[T]he fact is that the person has $\$ 25,000$ more to leave to his estate if he dies, which is certainly an increment." Mrr. Eustace Seligman, id. at 79. Cf. statements of Professor Groves, id. at 73-4, and Professor Shoup, id. at 79-80. 
gains. Even so confirmed an advocate of special treatment of capital gains as Mr. George O. May has recognized that "the great accumulations of wealth by individuals in this country have largely been the result of capital gains, and the salary or wage-earning classes might naturally feel that they were being unjustly discriminated against if they were taxed on their salaries or wages and the large capital gains of the very wealthy should escape taxation." 42

The regressive tendency of the present treatment of capital gains may be seen from the fact that an individual does not find it to his advantage to employ the $50 \%$ "alternative rate" authorized in Section 117 (c)(2) unless his "surtax net income" ${ }^{43}$ " (including net capital gains) is large enough to be taxed at an effective graduated rate in excess of $50 \%$. Under the rate scale enacted in 1948, ${ }^{44}$ the "alternative rate" was of no assistance to an unmarried individual receiving less than $\$ 22,000$, or to a married couple receiving less than $\$ 44,00046$ who elected to file a joint return and thereby to "split" their combined income. ${ }^{46}$ It is therefore apparent that the resultant $25 \%$ tax ceiling benefits only relatively prosperous taxpayers and these in direct proportion to their prosperity. Less affluent taxpayers benefit solely from Section 117(b) which provides that only half of their "long term capital gains" need be included in their "ordinary income."

The full significance of these provisions can only be appreciated in

42. May, The Taxation of Capital Gains, 1 Harv. Bus. Rev. 11, 12 (1922).

"From a practical commonsense point of view there is something strange in the idea that a man may indefinitely grow richer without ever being subject to an income tax." Douglas, J., dissenting in Helvering v. Griffiths, 318 U.S. 371, 409 (1942), quoting from Powell, Income from Corporate Dividends, 35 HaRv. L. Rev. 363, 376 (1922). Cf. Statement of Randolph E. Paul, Tax Advisor to the Secretary of the Treasury, Hcarings bcforc Committee on Way's and Means on HJR. 6358, 77th Cong., 2d Sess., 1611, 1630-1 (1942). "The corollary phenomenon is that a man may lose the greater part of his fortune and have no deductible losses, so long as he has not realized those losses by sales, and the properties in question have not become absolutely worthless." Magill, Taxable Income 81 (1945). This symmetry is superficial; the property owner is usually free to realize losses and to abstain from realizing gains as it suits his tax advantage.

43. INT. Rev. CoDE § $12(\mathrm{a})$.

44. INT. REv. CoDE $\S \S 11$ and 12, as amended by the Revenue Act of 1948, $\S 101,62$ STAT. 111 (1948). Although capital gains were once taxed at $123 / 2 \%, \S 206(\mathrm{~b})$, Revenue Act of 1921, 42 STAT. 233 , the present $25 \%$ maximum rate is at least as favorable in comparison with contemporaneous surtax rates. "An important fact to be kept in mind is that during a large part of the period in which the $12 \mathrm{x} / 2$ per cent [capital gain] rate was in effect, the top surtax rate on ordinary income was only 20 per cent, whereas the present [1937] surtax rates reach 75 per cent." Report of Subcommittce, Hearings before Committee on Ways and Means on Proposed Tax Revision, 75th Cong., 3d Sess. 37 (1938).

45. See United States Individual Income Tax Return for 1948, Form 1040, Schedule D.

46. The "income-splitting" provisions of the Revenue Act of 1948 are described in SEN. Rep. No. 1013, 80th Cong., 2d Sess. 52 (1948). 
the light of the available statistics as to the distribution of capital gains among the various income groups.

"In 1938, a fairly typical year, capital gains constituted less than 1 percent of the net income reported by persons with incomes under $\$ 5,000$, about $31 / 2$ percent of the net income of persons with incomes between $\$ 5,000$ and $\$ 25,000$, and about 11 percent of the net income of persons with incomes over $\$ 25,000.37$

"Capital gains compose a larger proportion of income, the higher the income. ${ }^{48}$ The income class from $\$ 100,000$ to $\$ 1,000,000$, for example, reported in 1938 only about 21/2 percent of aggregate net income, but it reported nearly 19 percent of capital gains. It is plain to see that the preferential rate for capital gains seriously interferes with the progressiveness of the income tax. ${ }^{43}$ Obviously a more fa-

47. Cf. Fagan, Economics of Capital Gains Taxation, Proc. Nax. TAx Ass'x 113, 122 (1939).

These figures shed considerable light on the figures employed in support of the argument that capital gains taxation is not required by revenue considerations. E.g." "The relative unimportance of the capital gains tax as a source of revenue is demonstrated by the fact that the peak amount realized in 1928 amounted to only 576 million dollars. Since 1934 the highest annual revenues to be collected from this source was 202 million dollars in 1943, which represented only $1.2 \%$ of total revenues from income and profit tases." Schram, Thic Fallacy of Taxes on Capital Gains, 161 Coararerctal and Frnancral Crrowicre 2606, 2631 (1945). Mfanifestly the low yield of the tax is attributable, not only to its low rates, but also to the fact that capital gains represent only a small percentage of the income of an even smaller percentage of the population. However, the utility of a tax cannot be measured solely by its productivity; otherwise such poor revenue producers as the federal estate and gift taxes would long ago have been replaced by a federal general retail sales tax. Even if unimportant from a revenue viewpoint, the taxation of capital gains is justifiable on the grounds (1) that "equity among individuals is impossible under an income tax which disregards such items of gain and loss. ..." Srarons, Personal Incoste Taxatron 157 (1938), and (2) that "the capital gains tax is designed not only to yield revenue directly, but also to prevent the avoidance of other taxes." Statement of Randolph E. Paul, Tax Advisor to the Secretary of the Treasury, Hearings before Committee on Ways and If cans on H.R. 6358, 77 th Cong., $2 \mathrm{~d}$ Sess. 1611, 1630 (1942).

48. Cf. Professor Seltzer in Caprtal Gains Taxatron 12, 13 (Tax Institute Symposium, 1946). Conversely the recipients of smaller incomes realize a disproportionately large share of capital losses, deduction of which is restricted by way of compensation for the lenience shown towards capital gains. Supplearental Refort on Capitur Garws arod Losses

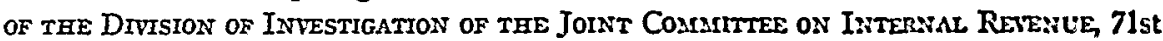
Cong., 1st Sess., 5 (1929); Groves, Postwar Tasation and Econositc Pigcress 216 (1946). See also Lowndes, supra note 6, at 448.

49. This is accentuated by the fact that the law favors long-term over short-term gains, and more than a proportionate share of long accruals are associated with the larger incomes. Taxpayers with net incomes of $\$ 25,000$ and less report the largest percentage of gains from assets held 1 year or less, while those taxpayers with net incomes of $\$ 50,000$ and over report the largest percentage of gains from assets held over 10 years. Report of Subcommittee, Hearings before Comnittee on IY ays and Mfeans on Proposed Tax Rerision, 75th Cong., 3d Sess. 39 (1938). Groves, Postivar Taxation and Econosic Progress 214 (1946). 
vorable treatment of capital gains would interfere further by benefiting primarily a small high income group." so

Because justice in taxation requires that income tax rates be progressive, a substantial burden of proof rests upon those who advocate exceptions to this principle. ${ }^{51}$ It is submitted that the allegations regarding the unfairness of subjecting capital gains to graduated income tax rates ${ }^{52}$ have not yet been established by that fair preponderance of the evidence which should be required to overcome the presumption in favor of taxing all types of income to the same extent. ${ }^{63}$

\section{B. Arguments Concerning Adverse Repercussions Upon the ECONOMY}

Even if special treatment of capital gains is not required for reasons of fairness, it might be defensible if it were needed to prevent substantial adverse repercussions upon the economy. Accordingly it is necessary to inquire into the merits of the latter type of argument.

\section{Deterrence of Potential Sales}

The argument is frequently made that the imposition of any substantial tax on capital gains will tend to deter sales which would otherwise take place. This argument receives support from several sources.

50. Paul, Taxation for Prosperity 275 (1946). Cf. 1929 Supplemental Rep., supra note 4 , at $1-4$.

These figures have an important bearing upon the validity of the argument that a "highly preferential treatment [of capital gains] is desirable in order to preserve the only means left whereby a poor man can get rich." Professor Seltzer in Capital Gains Taxation 13-14 (Tax Institute Symposium, 1946). They suggest that it is rarely the "poor man" who benefits by such treatment.

The tremendous tax savings afforded to taxpayers in the higher surtax brackets by the capital gains provisions received widespread public attention when the Bureau of Internal Revenue ruled that as an "amateur" writer, General Dwight D. Eisenhower realized longterm capital gain rather than ordinary income upon the sale of the copyright to his memoirs. "Thus General Eisenhower will pay about $\$ 520,000$ less than would a professional writer, if his memoirs bring him $\$ 1,000,000$." N.Y. Times, June 2, 1948, p. 31, col. 5 .

The public was shown the other side of the coin when the Bureau ruled that comedian Jack Benny was not entitled to $25 \%$ capital gain treatment upon the transfer of his incorporated radio show from N.B.C. to C.B.S. Cf. article headlined "Oh, Rochesterl Jack's Tax Bill \$3,080,000," N.Y. Daily News, Dec. 31, 1948, p. 3, col. 3-5.

51. This is because "[c] apital gains constitute real taxpaying ability to the recipient, no less than equivalent income derived from other sources." 1938 Subcommittee Rep., supra note 49 , at 38 .

52. Cf. note 44 stipra.

53. Professor Simons finds the case for special treatment so unconvincing that he attributes to its advocates a desire to facilitate the avoidance of progressive tax rates. According to Simons: "If you don't like your surtaxes, look for loopholes in the tax base. If no adequate ones are found, write to your congressman about capital gains taxes and tell the world that they are ruining business. Don't waste breath on the surtaxes. Face the problem realistically (but never frankly) for what it is, namely, a shortage of convenient loopholes." Simons, Federal Tax Reform, 14 U. of CHr. L. REv. 20, 21 (1946). 
For example, a congressional committee concluded that, during the years 1917 through 1921 when capital gains were treated no differently from other types of income, "the very high surtax rates forbade the taking of profits and encouraged the taking of losses." 34 Less plausible is the assertion that the present " 25 percent rate on securities held more than six months is a real barrier to the fluidity of capital." is Nevertheless there is some merit in the argument that any tax in excess of a nominal rate tends to discourage sales.

"[A] high capital gains tax is definitely a deterrent to realization. How great it is, is another question, but certainly if I have a security which is paying me dividends, and if when I sell it I am going to pay in tax half the proceeds and have only half to reinvest, I shall not be able to get the same income I had and, therefore, I shall be torn between the desire on the one hand to keep my income up, and on the other, to sell the stock before it begins to reach the top; "5s so there is some deterrent." 57

It should be observed, however, that if special treatment of sales by investors is required because of the alleged deterrent effects of high tax rates, it would seem no less necessary both (a) in the case of sales by "speculators" of property held for six months or less and (b) in the case of sales by "businessmen" of "property held primarily for sale to customers." Yet profits realized upon both (a) and (b) are subject to surtax. One might well suppose that the incidence of deleterious economic effects would not depend on the legal classification of the seller's activities.

It is arguable, however, that, whereas a typical "investor" has the alternative of enjoying a recurrent yield if he refrains from selling, a "speculator" holding commodity futures or a "businessman" holding an inventory of shoes has no choice but to sell if he is to get his money

54. Report of the Joint Coararittee on Internal Revenue Taxation 43 (1927). Cf. Supplentental Rep., supra note 4, at 8.

55. Franklin Cole in Capital Gains Taxation 50 (Tax Institute Symposium, 1946). That this impression is so widespread is largely attributable to the fact that many businessmen and attorneys have had personal experience with a deal which failed to go through because of what the seller considered to be his tax advantage.

56. "If the owner thinks that the security will go still higher, he should keep it, regardless of the tax. If he thinks that it is going lower, it will pay him to sell, as long as the tax: is less than 100 per cent. If he does not know what to think, he would still not know what to think even if there were no taxation of capital gains." SHoup, et al., FAcrisc TaE TAx Problears 489 (1937). "However, if an individual plans to get out of the market, he will want to get out as near the top as possible, tax or no tax. It is clearly in his interest to pay the tax on a larger gain than on a smaller gain." Statement of Randolph E. Paul, Tax Advisor to the Secretary of the Treasury, Hearings before the Commilfec on IWays and Means on H.R. 6358, 77th Cong., 2d Sess. 1611, 1631-2 (1942).

57. Eustace Seligman in Capital Gains Taxation 15 (Tax Institute Symposium, 1946). 
out. Accordingly, the "speculator" and the "businessman" would not be deterred from selling by the surtax on their sales profits. This distinction can be no better than the categories upon which it is based. Thus if the short-term "speculator" held stocks and sold them notwithstanding the surtax, it was not because he had no alternative but merely because he preferred a quick turnover of his capital at a narrow profit margin to a dividend income from quasi-permanent investments. In Gilbert v. Commissioner ${ }^{58}$ the taxpayer's sale of preferred stock which he received as compensation for his services as a building contractor was treated as a "business" transaction, giving rise to ordinary income or fully deductible loss, although he could have retained the stock for whatever dividends they might have yielded. On the other hand, in United States v. Robinson ${ }^{59}$ the sale of timber inherited from the taxpayer's father was treated as an "investment" transaction, giving rise only to capital gain or loss, although Miss Robinson had little real choice but to sell the timber if she was to realize any income from it. Thus there appears to be no substantial correlation of "investment" with a choice between selling and not selling, and "business" and "speculation" with the absence of such a choice. On the contrary, there seems little in the character of the various classes of transactions to justify so much solicitude for the deterrence of sales of capital assets and so little for the deterrence of sales of other types of property.

Assuming however that "some deterrent" 60 exists even under the present lenient treatment of capital gains, there remains the question of its magnitude. It would seem that this depends less upon the absolute size of the ceiling rate-now $25 \%$-than it does upon the relationship which that rate bears to the surtax rate applicable to the seller's ordinary income. This has been demonstrated by Eustace Seligman ${ }^{61}$ as follows: Assume that a man holds stock upon which he receives dividends of $\$ 100,000$ a year. Assume further that, for tax purposes, the cost basis of this stock in his hands is zero, so that if he sells the stock, the entire sales proceeds will be subject to a $25 \%$ capital gains tax. Therefore if he sells and reinvests the proceeds remaining after payment of the $25 \%$ tax in another stock with the same yield, he will receive yearly dividends of $\$ 75,000$ instead of $\$ 100,000$ becausc his capital will have been depleted by $25 \%$. This decrease in dividend income is more likely to deter the sale if the stockholder's dividend income is taxed at a $50 \%$ rate than if it is taxed at an $80 \%$ rate. This can be seen from the fact that the decrease in dividend income from

58. 56 F.2d 361 (1st Cir. 1932), reversing 21 B.T.A. 1245 (1931), discussed in Part I.

59. 129 F.2d 297 (5th Cir. 1942), discussed in Part I.

60. Eustace Seligman in Capital Gains Taxation 15 (Tax Institute Symposium, 1946).

61. See Seligman, id. at 57-8; cf. George O. May, id. at 54; Thomas N. Tarleau, id. at 56; Harry J. Rudick, id. at 57. 
$\$ 100,000$ to $\$ 75,000$ will cause a decrease from $\$ 50,000$ to $\$ 37,500$ in dividend income remaining after payment of a $50 \%$ income tax and a decrease from $\$ 20,000$ to $\$ 15,000$ after payment of an $80 \%$ income tax. Thus, whereas the drop in dividend income remaining after income tax is $\$ 12,500$ with a $50 \%$ rate, it is only $\$ 5,000$ with an $80 \%$ rate. As one may assume that an investor will be less reluctant to sacrifice $\$ 5,000$ a year than $\$ 12,500$ a year, it follows that the capital gains tax is less of a deterrent to a man subject to an $80 \%$ rate than it is to a man subject to a $50 \%$ rate.

This line of reasoning suggests that the present capital gains tax is not likely to constitute a serious deterrent to sales of appreciated stocks so long as surtax rates remain high. While they do, the alternative to a $25 \%$ maximum tax on the sale of stocks backed by undistributed corporate earnings will often be a much higher tax on the distribution of dividends. ${ }^{62}$ Reinvestment of the balance left after the payment of the dividend tax would involve a much greater reduction in future income than the reinvestment of sales proceeds after payment of the present capital gains tax. ${ }^{63}$ Thus any deterrent effects of the partial tax on capital gains would seem in large measure counterbalanced by the inducement to sell afforded by the partial exemption.

Willingness to sell depends not only upon the relationship of the capital gains rates to ordinary surtax rates but also upon the treatment of gains accrued but unrealized by sale prior to the death of the property owner. Section 113(a)(5) of the Internal Revenue Code provides that when a legatee sells property "acquired by bequest, devise, or inheritance . . . the basis shall be the fair market value of such property at the time of such acquisition." Hence if an asset cost $\$ 1,000$ originally, was worth $\$ 3,000$ when its owner died, and was sold by his heir for $\$ 3,500$, the $25 \%$ maximum rate would apply only to a gain of $\$ 500$. The $\$ 2,000$ increase in the value of the property which accrued prior to death escapes the capital gains tax. Thus elderly property owners are offered a substantial inducement for refraining from profittaking. ${ }^{64}$ This factor has great practical importance.

"[U]nwillingness . . . to make exchanges in the face of a high tax is ... perhaps more due to this loophole in the system than

62. Cf. Thomas N. Tarleau in Caprtal Garns Taxation 55 (Tax Institute Symposium. 1946). See also Report of Subcommittee, Hearings before the Commillee on IWays and Means on Proposed Tax Rerision, 75th Cong., 3d Sess. 39 (1938).

63. Of course, if the distribution could be arranged so as to comply with the rather strict requirements of a "partial liquidation", it would first constitute a ta:s-frce return of capital which would reduce the basis of the "redeemed" stock to zero and then would become capital gain. See Part I, notes 235-237 of this article.

64. See discussion by Franklin Cole in Capital Gaiss Taxatro: 49 (Tax Institute Symposium, 1946). 
to the tax itself. If one is to be taxed eventually on the appreciation of assets, he is less likely to defer an exchange than ... . [if] the possibility exists of not being taxed at all." 65

If there is concern that the capital gains tax deters sales, this concern may be alleviated substantially by elimination of the provision which immunizes gains accruing prior to death. ${ }^{66}$ Otherwise reluctance to sell will often be attributable to this opportunity for tax avoidance rather than to the tax itself. 67

\section{Distortion of Market Values}

The argument is often made that the taxation of capital gains results in artificially inflated prices for capital assets because the owners of such assets which have appreciated in value may sometimes choose not to sell them rather than pay the tax on their gains. ${ }^{68}$ However, even if it be assumed that taxation deters the sale of appreciated assets, it does not necessarily follow that "a deferring of sales ... means a subtle diminution in the floating supply of securities, which, in turn, means that a bullish force is unleased that has nothing to do with the intrinsic value or merit of the securities." 69

Many potential transactions are of a type which may be deterred without any substantial influence on the market:

"The effect of the capital gains tax on the prolongation of a price rise depends on whether it merely discourages people from switch1946).

65. Professor Groves in Capital Gains Taxation 19 (Tax Institute Symposium,

66. Appropriate amendments are discussed by VICKREY, Agenda fon Progressive TAXATroN 140 (1947). Tannenbaum, Basis of Property Transmitted at Death-Necd for Revision, 3 Tax L. Rev. 166 (1947). Cf. discussion in Capital Gains Taxation $39-42$ o(Tax Institute Symposium, 1946).

67. This comment is always applicable whenever sales are postponed because of the desire to retain use of tax money for as long as possible. Cf. VICKREY, AGENdA FOR ProciResSIVE TAXATION 144 (1947).

68. "To a considerable extent, the inflation of values which culminated in 1929 may be attributed to this cause. . . " Cole, Treatment of Capital Gains and Losses for Income Tax Purposes, 14 Tax MaG. 583, 584 (1936). "Europeans blamed the stock market on the mercurial temperament of the American people and on the violent changes in our weather. The real culprit was the capital gains tax." Friedman, Memorandum in Hcarings bcforc Committee on Ways and Means on H.R. 6358, 77th Cong., 2d Sess. 1656, 1662 (1942).

But see Hogan, The Capital Gains Tar, 9 TAx Mag. 165-6 (1931): "While it may be admitted that any tax, however small, based upon realized profits will to some extent cause the postponement of profit-taking, it is rather difficult in the light of past events to subscribe to the view that a $12 \mathrm{1} / 2$ per cent tax on profits precipitated one of the most serious cconomic crises in the history of the country. Especially in view of the fact that from 1913 to 1921 such profits paid a tax rate at times as high as 73 per cent, which it seems reasonable to as. sume exercised a much greater restraint upon profit-taking than the $121 / 2$ per cent rate, and yet we find no evidence during this period of nearly nine years of any inflation in security values comparable to that which is now said to have resulted from the $121 / 2$ per cent rate."

69. Seidman, Income Taxes and Bull Markets, Barron's, Feb. 24, 1936, p. 3, col. 2. 
ing from one security to another or also discourages sales by persons who would not at once buy some other security. The discouragement of 'switching' sales clearly has little or no effect on the marliet .. . [because] the purchase of one stock, which tends to increase its price, is preceded or accompanied by the sale of another stock, which tends to reduce the price of that stock.

"[Only] to the extent that the capital gains tax discourages sales that would not have been followed by repurchases is the level of the market affected." 70

Thus it would seem that the degree to which asset values are influenced is not susceptible of simple generalization. ${ }^{71}$

If a capital gains tax deters people from cashing in on appreciated investments, it should also in some degree deter them from entering into transactions where appreciation rather than recurrent yield is probable..$^{2}$ Hence the alleged reduction in the "supply" of such assets would, at least in part, be balanced by a reduction in "demand" and little pressure would be exerted on the market, either downward or upward. ${ }^{73}$

But this does not mean that the present capital gains tax has no inflationary effect.

"[I]f the 25 per cent rate on capital gains, compared to rates up to 70 or 80 per cent on ordinary income, is a barrier to selling, and therefore cuts down supply, does it not also stimulate demand? Has it not presented an inducement for people to get into the market as a way to make money with only a small tax, and is it not accordingly responsible to some extent for the boom itself?" 74

As there seems to be little doubt that the $25 \%$ tax ceiling "does en-

70. Paul, Hearings before Commitfec on Ways and Means on H.R. 6358, 77th Cong., 2d Sess. 1631 (1942).

71. It may be significant that, despite the absence of a capital gains tas in Great Britain, the British stock market "moves the same as ours." Harry J. Rudich in Caritar. Garss Taxation 63 (Tax Institute Symposium, 1946).

72. However, the prospect of a future capital gains tax will not deter the purchase of property to be retained until the purchaser's death. See discussion of IxI. REv. ConE $\$ 113(\mathrm{a})(5)$ sipra.

73. "The fact should be stressed that the capital gains tax may not only increase the reservation prices of certain assets but that it may also decrease the market demand, in the schedule sense, for speculative assets." Fagan, The Economics of Capilal Gains Taxalion, Proc. NAt. Tax Ass'N 113, 120 (1939). "[T]he absence of stock offerings means the absence of demand for stocks too. It appears on both sides of the equation and consequently may not greatly affect the trend in stock prices one way or the other." Professor Groves in Capital Gains Taxation 60 (Tax Institute Symposium, 1946). Cf. Eustace Seligman, id. at 63. In opposition to this view, Professor Somers argues that the capital gains tax deters sales to a greater extent than it does purchases and that therefore it exerts an inflationary influence. Somers, An Econonic Analysis of the Capital Gains Tax, 1 NAT. TAx J. 226, 227 (1948).

74. Roy Blough in Capital Gains Taxation 61 (Tax Institute Symposium, 1946). 
courage [people] to go into the market to buy," 75 it would appear that the present scheme of taxing capital gains may well exert some inflationary influence-not because of the partial tax but because of the partial exemption.

The argument that the present capital gains provisions exert an unhealthy influence on prices because they create "a greater number of unwilling sellers" ${ }^{76}$ is subject to still another criticism. If stock market booms are intensified by even limited recognition of capital gains, then market downswings are retarded by the limited recognition of capital losses which historically ${ }^{77}$ has accompanied limited recognition of capital gains. Less-than-full deductibility tends to reduce the incentive to sell high-cost properties for the purpose of obtaining tax deductions. Yet even such limited deductibility of capital losses has been thought to accelerate a decline in market values. ${ }^{78}$ This alleged evil seems effectively forestalled, however, by the $\$ 1,000$ limitation upon the deductibility of net capital losses from ordinary income. ${ }^{79}$ True, the present "carry-over" of net capital losses ${ }^{80}$ may invite tax selling where the taxpayer expects to realize capital gains within the next five years. But any depressive effect of such sales is likely to be at least partially offset by the stimulus to reinvestment afforded by the prospect of future gains which will be tax-free to the extent of the unused deduction for past losses. ${ }^{81}$

\section{Discouragement of Useful Transfers}

Another type of argument predicated upon the assumption that the taxation of capital gains acts as a deterrent to profit-taking is that

75. George O. May, id. at 62 .

76. Schram, The Fallacy of Taxes on Capital Gains, 161 Connercial and Finnncral Chronicte 2606, 2631 (1945).

77. Simons, Personal Income Taxation 160 (1938). Cf. Report of Joint Committee on Internal Revenue Taxation 7 (1927) ; Professor Lawrence H. Seltzer in Caritar. Gains Taxation 13 (Tax Institute Symposium, 1946) ; Lowndes, The Taration of Capital Gains and Losses under the Federal Income Tax, 26 Texss L. REv. 440, 448 (1948).

78. "[I]]n a recession, by switching from one stock to a similar stock, speculators and investors could realize capital stock losses without sacrificing the chance for future recovery. ... [I]f simultaneously with the sale of one stock, another is bought, no general pressure úpon the market results. However . . . some stockholders in periods of recession sell to establish losses, but, expecting further declines, wait for a chance to buy at still lower prices. [But] if stockholders expected a further decline in the price of stocks, they would sell and buy in at a lower level regardless of the existence of a capital gains tax." Faganl, The Economics of Capital Gains Taxation, Proc. Nat. Tax Ass'N 113, 121 (1939); af. Colm \& Lehman, Economic Consequences of Recent American Ta.r Policy, Socrat RESEARCH, Supplement 1, p. 68 (1938).

79. INT. Rev. Code $\$ 117$ (d) (2). Cf. Paul in Hearings before Committce on Ways and Means on H.R. 6358, 77th Cong., 2d Sess. 1631 (1942).

80. INT. Rev. CODE $\$ 117$ (e).

81. Cf. Paul, supra note 79, at 1631. 
espoused by the late Andrew Mellon while Secretary of the Treasury. In his illustration, the holder of a parcel of real property which has appreciated in value is attracted by an offer from a purchaser "who would improve it with buildings." Upon reflection, however, the sagacious landowner decides to "keep the property [rather] than sell it, pay the tax, and invest what is left in something else."

"What is the result? The transaction does not take place and the community loses the advantage which would come in the stimulation that would arise from the transactions resulting from the buyer's improvement of the property, and it also loses the advantage of the seller's putting his money into some other form of investment which in turn would give rise to business transactions." 82

Consequences such as these constitute a plausible argument against capital gains taxation, not only because they are important, but also because their causation is easily traced.

However, other less easily traced repercussions have been ascribed to the taxation of capital gains, even under the present lenient $25 \%$ after-six-months scheme.

"I doubt whether those persons who wish to see a longer holding period and a higher rate appreciate what the consequences would be. . . . [W] already have gone as far as we can go safely. Any more drastic interference with the transfer of capital assets would check the flow of venture capital, would put a brake upon the operation of job-creating processes, and would, in my judgment, result eventually in a frozen economy." " s3

This argument presumes correctly that if the taxation of capital gains hinders the sale of appreciated property, such taxation will also often deter the purchase of property acquired in expectation of future appreciation. It also appears likely that progressive tax rates tend to reduce

82. Rep. Sec. Treas. 19 (1921). It should be noted that Secretary Mlellon's argument was directed against the taxation of capital gains at full progressive rates without regard to the duration of their accrual.

83. Schram, The Fallacy of Taxes on Capital Gains, 161 Cosmercint nst Frna:erar. Chronicle 2606, 2631 (1945). Cf. Nelson, Capital Gains Tax Dams Rist: Funds, N.Y. Times, Sept. 26, 1948, \& 3, p. 1, col. 4 .

In support of this conclusion it is argued that under present law the Government enjoys a "heads I win, tails you lose" position zis d vis the taxpayer. "If a man malies $\$ 20,080$ on an investment in industry, he must pay a tax up to 25 per cent. But if he loses $\$ 20,000$-and does not have a capital gain to offset it-he is out of luck. Only $\$ 6,000-\$ 1,000$ a year for six years-can be deducted from his regular income. And the permissible deductions are no bigger if he loses $\$ 100,000$ or $\$ 1,000,000$. That is his worry." Beclsy, Taxes: Cutting Our Nose to Spite Our Face, Newsweek, Dec. 19, 1949, p. 55. It should be observed that this argument pertains to the treatment of capital losses, not capital gains.

For a less pessimistic view, see Somers, An Economic Analysis of the Cafital Gains Tax, 1 Nat. Tax J. 226, 232 (1948). 
the volume of private capital employed in profit-making ventures. ${ }^{84}$ Nevertheless, it does not necessarily follow that partial exemption of capital gains is an appropriate means of counteracting the possible effects which graduated tax rates may have upon incentives. As a subsidy to the productive utilization of private resources, both human and financial, such special treatment operates capriciously. It furnishes an incentive neither to the expenditure of energy in occupations generating wage and salary compensation nor to the expenditure of funds expected to yield income in the form of dividends, interest, rents, and royalties. Furthermore, no direct encouragement is given the sale of ordinary merchandise. These considerations should be kept in mind in evaluating the contention that favored tax treatment of capital gains is required to provide the incentives essential to a profit-motivated economy. ${ }^{85}$ They suggest that such treatment furnishes an incentive only to owners of capital, and not even to all owners of capital but only to those who are able to arrange their affairs so as to realize income in the form of capital gains. The rest of the community is afforded no incentive whatever.

As any tax on income can be considered a deterrent to economic activity, it would seem that solicitude for capital gains is justified only if taxation of this type of income is a greater deterrent to the utilization of private resources than is the taxation of other types of income. ${ }^{89}$ There appears to be little reason to think that incentives are affected more adversely by the taxation of profits realized upon the sale of property than by the taxation of compensation, dividends, and other forms of income. ${ }^{87}$ Nor is it clear that taxation of capital gains realized by investors has a more undesirable effect upon incentives than equal taxation of ordinary profits realized by businessmen upon the sale of "property held ... primarily for sale to customers. . . ." It would seem, therefore, that if risk-taking is to be accorded special treatment,

84. "Increased tax burdens . . . force users of capital to restrict their commitments to undertakings in which the expected gross marginal return, before taxes, is higher than that which was thought adequate before the tax increase. At any time there must, obviously, be a smaller number of possible undertakings offering these higher marginal returns than those offering prospects for lower returns. In addition, the degree of certainty with which this higher marginal return can be expected is usually less. . . . This decrease in the degrco of certainty also operates independently to reduce the attractiveness and hence the volume of current new investment." ANgell, Investurent and Business Cycles 276 (1941).

85. See George O. May in Capital Gains Taxation 22 (Tax Institute Symposium, 1946).

86. Paul in Hearings before Committee on Ways and Means on H.R. 6358, 77th Cong., 2d Sess. 1633 (1942).

87. "If the rates are too high to be good for incentives in one case, they probably are in the other. Parity treatment for losses would be one way of compensating for equal treatment of capital gains so far as the effect on enterprise is concerned." Professor Groves in CAPITAL Gains Taxation 18 (Tax Institute Symposium, 1946). 
methods more comprehensive than those of the present capital gains law should be devised. ${ }^{\text {Ss }}$

Even if it be true that the taxation of capital gains tends to deter the sale of appreciated property, this may not be an unmitigated evil.

"[W] can't be sure that some reduction in the amount of exchange, or the number of exchanges of investments, would be socially bad. It is often observed that this buying of securities for appreciation results in a very fleeting citizenship in American corporations. ${ }^{89}$ Stock owners often take very little responsibility and acquire very little information about the companies they own because their ownership is so highly transitory. . . ." "E "[This] results in further abdication of the stockholder to management. ..." "91 "[It may not be] in the social interest for realization to be entirely unimpeded by any tax laws and to be extremely easy ..." [if it is] "desirable to have more people regard stock as an investment and less as a speculation." 92

There is a still more important reason for belief that the public interest would not be affected adversely by the deterrence of some types of transactions. Many individuals in the higher surtax brackets, such as experienced corporate executives, have become increasingly aware that, whereas their income from the pursuit of their vocations is taxed at rates of perhaps $60 \%$ or $70 \%$, whatever profits they may receive from long-term stock market operations will not be taxed in excess of an effective $25 \%$ rate. Accordingly it seems probable that much time, energy and capital has been channelled in the latter direction, and away from directly productive activities in business and the professions. ${ }^{93}$ Although it is impossible to say how far this tendency has progressed, the gravity of its implications for the future of private

88. Thus Mr. Rudick asks: "Assuming we are thinking of allowing a favorable rate to gains from venture capital, is six-month capital really venture capital? Can a new business actually get going in six months?" Capital. Gaims Taxntrox 87 (Tax Institute Symposium, 1946).

89. "It is rare, one is told, for an American to invest, as many Englishmen still do, 'for income'; and he will not readily purchase an investment except in hope of capital appreciation." Keynes, The General Theory of Earployarent, Intenest asid Moner 159 (1936). According to Professor Groves, "the purchase of stoels for increment . . . means that stocks are valued by guesswork at the trend in the stock market and not according to their inherent value; that aggravates stock market booms and depressions." Capital Gatns Taxation 65 (Tax Institute Symposium, 1946).

90. Professor Groves in Capital Garns Taxation 19 (Tax Institute Symposium, 1946).

91. Id. at 65 .

92. Id. at 60 .

93. "[W]e have made speculation too cheap to keep the businessmen at work, since if they put their earnings into businesses they are taxed at high rates, but they can speculate at a 25 per cent rate." Roy Blough in Capital Gains Taxatios 87 (Tax Institute Symposium, 1946). 
capitalism is readily apparent. ${ }^{94}$ This phenomenon alone should raise serious doubts as to the wisdom of a tax system whereby the intellectual and financial resources of many potentially creative citizens are siphoned off from the more socially-useful types of activity. ${ }^{05}$

\section{Other Economic Considerations}

Although hardly exhaustive, the preceding analysis of the undesirable economic consequences alleged to flow from the taxation of capital gains serves to indicate that these effects do not constitute a sufficiently strong argument against this type of taxation, ${ }^{90}$ especially if the applicable rates are as low as those prevailing under present law. Whether such an argument could be made out if capital gains were taxed more rigorously is, of course, another matter. Unfortunately, however, adequate statistical data is not yet available from which the magnitude of these effects at various rate levels might be calculated.

Even at a single rate level it is impossible to ascertain which of the alleged repercussions are trivial and which substantial. This is because these repercussions are demonstrated by deductive reasoning rather than by empirical research. Although unsatisfactory, this type of analysis must be accepted until more refined methods are developed. However, in view of the dearth of quantitative information as to the relative importance of the contradictory economic factors, it would seem that the principle of taxing all types of income to the same extent, i.e., at graduated rates, should be permitted to control practical policy.

\section{Conciusions}

The preceding discussion indicates that no satisfactory line has been drawn between capital gains and ordinary income, either in practice or in theory. Not only are the capital gains provisions seriously inefficient in attaining their presumptive end-the isolation and special treatment of "investment"- but it is far from clear that this end is worthy of attainment.

94. Cf. Professor Groves, id. at 65 .

95. Roy Blough, id. at 86. This problem has given rise to the suggestion that corporate executives would be less likely to stray from their jobs if their compensation were taxed at capital gain rates when received through the medium of stock options and other forms of bargain purchases. The objections to this suggestion are discussed in Miller, The Treasury's Proposal to Ta.e Employees' Bargain Purchases: T.D. 5507, 56 YALtE L.J. 706 (1947).

96. In this connection one should keep in mind that "[t]he bulk of capital assets is relatively insensitive to the character of our capital-gains taxation. 'This is true of the part held quasi-permanently for purposes of control and income. It is also true of the part employed in the short-term operation of traders and speculators, operations which normally account for a large fraction of the total trading in listed securities. . . " Report of Subcommittee, Hearings before Committee on Ways and Mcans on Proposed Tax Revision, 75th Cong., 3d Sess. 9, 40 (1938). Cf. Fagan, The Economics of Capital Gains Taxation, Proc. Nat. Tax Ass'N 113, 120 (1939). 
Section VI has demonstrated that many of the arguments advanced in support of favored treatment of "investment" gains may be refuted by deductive reasoning. Other arguments lack empirical support. Still others fail to mesh with the existing legal categories. It is submitted that, taken together, these arguments do not furnish adequate justification for so substantial an exception to the principle of progression as is found in the capital gains provisions.

Sections I through $\mathrm{V}$ have indicated that, in addition to difficulties concerning their theoretical bases, these provisions present substantial difficulties in their practical application. The issue here has been stated well by Professor Seltzer:
"There are many types of ordinary income that resemble capital gains and vice versa to such an extent that to draw the line is arbitrary. Is that true to such an extent that we ought to consider removing the distinction between capital gains and ordinary in- come?" 97

An affirmative answer to this question appears to be required by the numerous and important anomalies described in Sections I through V. These Sections also suggest that even substantial legislative and judicial improvements in the criteria for segregating capital gains may not be sufficient to eliminate such anomalies and that "any special treatment of capital gains per se . . . requires introduction into the law of arbitrary, unsatisfactory, and unnecessary distinctions." $\varepsilon 3$

It is submitted that capital gains should be taxed at the graduated rates applicable to income received in other forms. Acceptance of this conclusion does not, however, necessarily require a return to the pre1922 law under which capital gains were taxed at full progressive rates in the year of realization regardless of the fact that some accrued over several years or represented highly irregular receipts. Although even this simple but crude method might well be preferable to the casuistic complexities of the present scheme of taxing capital gains, a truly adequate solution of the problem is probably unattainable without a thorough revamping of the entire structure of the income tax.

It is common knowledge that such a solution depends, in large measure, upon whether corporate profits can be integrated into the personal income tax base in a manner more satisfactory than that effected by the present irrational hodgepodge of corporate taxes, ${ }^{, 3}$ penalty taxes, ${ }^{100}$ and dividend taxes. ${ }^{102}$ Thus, if there could be devised

\footnotetext{
97. Capital Gains Taxation 46 (Tax Institute Symposium, 1946).

98. Sinsons, Personal Incone Taxation 152. See also, id. at 150.

99. INT. Rev. CoDE $\$ 13,14$ and 15.

100. INT. Kev. CODE $\S \S 102$ and 500.

101. INT. Rev. CODE $\$ 22$ (a).

Cf. How Shall Corporations Be Taxen? (Tax Institute, 1947); Goode, Tue
} 
some feasible method of taxing stockholders, like partners, on all current earnings regardless of distribution, ${ }^{102}$ the accompanying upward revision of the cost "basis" of the stock would substantially reduce the amount of the gain recognized for tax purposes when the stock is later sold. ${ }^{103}$ This would eliminate much of the hardship which otherwise might result from the application of progressive rates to gains realized upon the sale of assets held for longer than one year. Mitigation of the impact of the surtax upon irregular and "pyramided" income might also be effected by employing as the tax base, not the income of a single year, but an average of several years' income. ${ }^{104}$ If all types of income were averaged, many of the arguments advanced in support of special treatment for capital gains would lose whatever force they may now have. ${ }^{105}$ It may also be feasible to modify the existing rule that gains are taxable only when realized by sale or exchange. ${ }^{106}$

The proper treatment of losses realized upon the disposition of "capital assets" presents a more difficult problem. Fairness secms to

Postwar Corporatton Tax Structure (Treasury Dep't, Division of Tax Research, 1946) ; Vickrex, Agenda for Progressive Taxation 150-63 (1947); Groves, Postwal Taxation and Econosic Progress 20-73 (1946) ; Final Report of the Commiltec of thi' National Tax Association on Federal Taxation of Corporations, Proc. NAT. TAx Ass'N 534, 632 (1939). Westfall, Integrating Federal Income Taxes on Corporations and theit Shareholders, 27 TAXes 236 (1949).

102. Cf. Int. Rev. Code $§ 182$. See the proposals made in How Sullu Corponations Be TAXED? 42-3, 51-2, 61-90 (Tax Institute Symposium, 1947); Vickrey, AGENdA Fon Progresstve Taxation 159-62 (1947); Groves, Postwar Taxation and Economic Progress 55-9 (1946) ; Proc. Nat. Tax Ass'n 555-6 (1939) ; Devine, Taxing Corporations as Partnerships, 26 Taxes 506 (1948). Cf. DeWind, Preferred Stock "Bail-Outs" and the Income Tax, 62 HARv. L. Rev. 1126, 1138 (1949).

103. "If all holders of stock were required to pay tax on their pro rata share of corpo. rate income as it accrues to the corporation, and were permitted to add undistributed corporate income on which they had been taxed to their basis for gain or loss on subseruent disposition of the security, the heart would be cut out of the capital gains problem. It would then be generally satisfactory to tax such gain as ordinary income in the year of its realization. . . " James, Irascible Comments on the Revcmue Lazus, 9 U. or Cur. I. Rev. 58, 70 (1941) ; cf. Parker, Capital Gains and Losses, 14 Tax Mag. 604, 610 (1936).

"Such a tax, if it could be upheld against constitutional attack and successfully administered ... would eliminate the entire problem of the accumulation of corporate surpluses to avoid surtax on the individual stockholders. The always unsatisfactory Section 102 and the highly controversial tax on undistributed earnings would be simply unnccessary." Furthermore this system would remove "the present pressure of the corporate income tax ... toward fixed debt and away from equity financing. . .." James, supra, at 67,69 . For further details, see $i d$. at $68-71$.

104. See note 11 supra.

105. See Section VI supra.

106. A step has already been taken in this direction. I.T. 3910, 1948-1 CuM. BuLL. 15; I.T. 3932, 1948-2 Cum. Bulz. 7, discussed in Note, Gratuitous Disposition of Property as Realization of Income, 62 HARV. L. REv. 1181 (1949); Miller, Gifts of Ineome and of Property: What the Horst Case Decides, 5 TAx L. Rev. 1 (1949). Cf. James, Irascibli" Comments on the Revemue Laws, 9 U. of CHI. L. Rev. 58, 71 (1941). 
require that losses of this type be reflected in taxable income to their full extent as are losses of other types, e.g., losses sustained in the operation of a business ${ }^{107}$ and losses resulting from casualties such as fire and flood. ${ }^{108}$ The case for this treatment of capital losses would become very strong if all capital gains were taxed at progressive rates. ${ }^{103}$ However, when the deduction of capital losses from ordinary income is permitted," "the taxpayer then adopts an opportunistic policy, and takes gains only when it doesn't cost a tax [because offset by contemporaneous losses], and takes losses to offset gains, dividends, interest and salary." "111 Such "tax sales" might well jeopardize the yield of the income tax during periods of falling prices." 12 "Moreover from the standpoint of capacity to pay, it does not seem fair that a person who has a large amount of ordinary income should pay little or no tax, simply because he is able to shift his investments in such a way as to show tax losses, when such methods of avoidance are not open to other taxpayers whose incomes consist chiefly of earnings and the like and who do not own any considerable amount of capital assets on which losses have accrued." 113 Although no completely satisfactory solution is as yet apparent, ${ }^{114}$ the introduction of a system of averaging might well ameliorate this problem. ${ }^{115}$

107. INT. REv. CODE $\$ 23(\mathrm{e})(1)$.

108. Int. Rev. CODE $\$ 23$ (e) (3).

109. Cf. Harry J. Rudick in Caprtal Gains Taxatiox 44 (Tax Institute Symposium, 1946).

110. See discussion in Section I supra, concerning the reasons for the 1934 amendment to the "trade or business" clause.

111. Cf. Harry J. Rudick in CaptTal Gands Taxatron 44-5 (Tax Institute Symposium, 1946); Latham, Taxations of Capital Gains, 23 Carrr. L. Rev. 30,34 n.13 (1935). From this phenomenon Mr. Rudick draws the conclusion that less-than-full recognition of both capital gains and losses is "in the interests of the revenue." Capital Garss Taxation at 45.

112. H.R Rep. No. 708, 72d Cong., 1st Sess.; 1939-1 Cuar. BuL., pt. 2, pp. 457, 505. Morgenthau in Hearings before Committee on $W$ ays and Mfans, 73d Cong., 2d Sess. 5-4 (1933) ; Hendricks, Federal Incone Tax: Capital Gains and Losses, 49 Hass. L. Rx: 262,281 (1935).

113. Hendricks, supra note 112; cf. Fagan, The Economics of Cafilal Gains Toxation, Proc. Nat. TAX Ass'N 113, 125 (1939). For a contrary view, see Lutz, Sliould Cofilal Gains be Taxed as Income?, 22 Butu. Nat. Tax Ass's 130, 134 (1937).

114. One possibility would be to provide that losses resulting from transactions in securities and real estate (the principal subjects of "tax sales") could be used only to offset fully taxable gains realized upon these types of property. If losses exceeded gain, the net loss could be carried forward as an offset against gains realized in later years, much as net capital losses are now carried forward. However, this solution is not very satisfactory because like the present law, it requires that a distinction be made between losses which could be deducted from ordinary income and losses which could not. Heorings before Committce on IVays and Means on H.R. 635s, 77th Cong., 2d Sess. 1611, 1635-6 (1942); cf. Paul, id. at 13-14; Fagan, supra note 113, at 125.

115. See note 11 supra. See Bravman, supra note 11, at 26: "[I]ndividuals may not 
The above comments are intended, not as a detailed blueprint of an ideal tax system, ${ }^{116}$ but merely as an indication of some of the adjustments which might appropriately accompany the elimination of the present capital gains provisions. In considering which adjustments would be desirable, at least two objectives should be kept in mind. First, that it is necessary "so to arrange matters that precisely the same tax liability will arise no matter when the taxpayer carries through his transaction and no matter what form he causes the transaction to assume." Second, that it is necessary "to evolve a method of purchasing mobility at a lower cost in terms of equity." 117 Both of these ends must be pursued simultaneously. To assert that they are incompatible is to deny that a private enterprise economy can function efficiently under an equitable system of taxation.

Pending thoroughgoing legislative changes in the treatment of capital gains and losses, it should be the policy of courts and administrators to apply Section 117 only to those situations which clearly are covered by its terms. Where serious doubts as to its applicability arise, they should be resolved in favor of the interpretation whereby gains will be fully includible in ordinary income and losses will be fully deductible from ordinary income. This policy could be implemented by a strict interpretation of the words "sale or exchange," combined with a liberal construction of the clause which excludes from the capital asset category all "property held by the taxpayer primarily for sale to customers in the ordinary course of his trade or business." 118

In the absence of detailed analysis of the court decisions, it is not feasible to elaborate here on the techniques available for the interpretation of the "sale" and "exchange" concepts. However, on the basis of the discussion in Sections II, III, and IV, it is possible to generalize as to the proper construction of the "trade or business" clause. This discussion indicates that several obstacles lie in the way of a more inclusive interpretation of this clause.

be so apt, as under the existing scheme, to sell their capital assets merely to establish losses for tax purposes. These transactions could be deferred and later consummated for busincss reasons only and the individual would still obtain the same tax benefit provided he continues to average his income."

116. In an unpublished monograph Professors Carl Shoup and William Vickrey of Columbia University have examined thirteen methods of taxing capital gains and losses, finding none completely satisfactory.

117. Haig, Wall Street Journal, April 13, 1937, p. 4, col. 4. "Fortuitous minor inequalities cannot wholly be excluded; but there must be no opportunities for deliberate systematic avoidance on a large scale, i.e., for altering substantially one's tax liabilitics without change in one's real income circumstances." Cf. Simons, Fcderal Tax Reform, 14 U. of CHI. L. REv. 20, 21 (1946).

118. INT. REv. CoDE $\S 117$ (a) (1). The clauses excluding various other classes of property from the capital asset category, e.g., depreciable property and stock in trade, do not seem as susceptible of expansion and contraction as the "trade or business" clause. 
Probably the most serious of these obstacles is the statutory requirement that property which has not been "held by the taxpayer primarily for sale" is to be classified as a capital asset. ${ }^{119}$ This requirement is troublesome largely because the courts apparently have assumed that its meaning is self-evident and have failed to appreciate its latent ambiguities. The statute is far from clear, however, as to the precise point in time at which the intention to sell must predominate over all other plans with respect to the property. From the fact that the statute does not employ the phrase "acquired by the taxpayer primarily for sale" the inference may be drawn that property need not fall into the capital asset category merely because its sale was not the primary purpose of its acquisition. ${ }^{120}$ On the other hand, the property must have been "held by the taxpayer primarily for sale" at least during the interval between the decision to sell and the consummation of the sale. ${ }^{121}$ Hence it would seem that this requirement may not be altogether inflexible. ${ }^{122}$

Less formidable impediments to the broadening of the "trade or business" clause are the grocery-store ${ }^{123}$ connotations which cling to the phrases "trade or business," "ordinary course," and "sale to customers." If a statute should be construed so as to give some effect to each of its provisions, then the "trade or business" clause should not be interpreted as merely duplicating the preceding clauses which exclude inventory and stock in trade from the capital asset category. ${ }^{124}$ But far more persuasive than this hoary maxim should be the economic fact that profit or loss realized upon a sale has neither more nor less effect upon the seller's ability to pay taxes because the sale was isolated, or nearly so, rather than recurrent, or because the buyer might not colloquially be called a "customer." For these reasons it is desirable that the mere absence of prior sales of similar property should not

119. Of course, if an asset happens to constitute real or depreciable property used in the taxpayer's trade or business, and has been held for more than six months, then it comes within the operation of $\$ 117(j)$.

120. The "trade or business" clause in INT. REv. ConE $\$ 117$ (a) (1) refers, not to the purpose for which property was "acquired," but to that for which it was "held," "[T] intention of Congress ... was to include in the comprehensive word 'held,' property which might or might not have been purchased primarily for the purpose of resale." Richards v. Commissioner, 81 F.2d 369, 373 (9th Cir. 1936).

121. But "[i]t should take no long argument to show that the isolated fact of the sale is not a conclusive indication of the purpose for which the property was held. . . ." Resnicl, Tax Problems in Liquidation Sales, 26 TAxes 1109, 1110 (1948).

122. Cf. Harold T. Avery, 47 B.T.A. 538 (1942) ; Gilbert v. Commissioner, 56 F.2d 361 (1st Cir. 1932), reversing 21 B.T.A. 1245 (1931); Goldsmith v. Commissioner, 143 F.2d 466 (2d Cir. 1944).

123. "The analogy to groceries is particularly strong." Professor Groves in Capisal Gatns Taxation 17 (Tax Institute Symposium, 1946).

124. Cf. Gilbert v. Commissioner, 56 F.2d 361 (Ist Cir. 1932). 
foreclose the possibility of a "sale to customers in the ordinary course of trade or business." 125

However to exorcise the bogey of non-recurrence is not to deprive "sale to customers" of its intended effect. As was indicated in Section I of this discussion, this phrase was inserted in the statute so that long-term stock market losses incurred by professional speculators could not be used to offset ordinary income but would be subject to the restrictions applicable to the deduction of capital losses. ${ }^{120}$ In the light of this legislative history, "sale to customers" must be interpreted so as to remove from the scope of the "trade or business" clause all transactions conducted over an impersonal securities or commodities exchange. Although it is clear that these transactions are not sales "to customers" within the meaning of the statute, the intended scope of the "to customers" requirement is not clear with respect to other types of sales. However, the legislative history is barren of any suggestion that Congress wished "sale to customers" to be interpreted so as to refer only to repeated sales of merchandise to a regular clientele.

The preceding paragraphs indicate that the "trade or business" clause possesses important and relatively unexplored potentialities for expansion. The development of these potentialities requires the exercise of considerable discretion. Thus it appears unfeasible to alter the status of transactions for which Congress clearly intended favored treatment, such as gain realized upon the sale of a home or upon the sale of securities held by the "average small investor." However with respect to transactions for which Congress intended no special benefit, the available techniques of interpretation should be employed to extend the coverage of the "trade or business" clause so that gains will be fully includible in ordinary income and losses fully deductible from ordinary income. ${ }^{22 \pi}$

Would this policy be successful in the courts? Probably only to a limited degree. It should not be overlooked that the statutory definition of "capital assets" is a residual classification. The statute does not purport to say what a "capital asset" is, but only what it is not; what is described is not the doughnut but the hole. Section 117(a)(1) enumerates certain classes of property, the sale of which gives rise to ordinary, i.e., business, income or loss and provides that all other

125. Cf. Gilbert v. Commissioner, supra note 124 ; Goldsmith v. Commissioner, 143 F.2d 466 (2d Cir. 1944).

126. Report of Conference Committee on H.R. 1385, 73d Cong., 2d Sess. 22, quoted in O. L. Burnett, 40 B.T.A. 605, 609 (1939), aff'd in part, 118 F.2d 659 (5th Cir. 1941); Gruver v. Commissioner, 142 F.2d 363, 368 (4th Cir. 1944).

127. As Judge Learned Hand remarked, " $[t]$ here is no surer guide in the interpretation of a statute than its purpose when that is sufficiently disclosed; nor any surer mark of over solicitude for the letter than to wince at carrying out that purpose because the words used do not formally quite match with it." Federal Deposit Insurance Corp. v. Tremainc, 133 F.2d 827, 830 (2d Cir. 1943). 
property falls into the catch-all "capital asset" category. ${ }^{123}$ Thus the capital asset concept includes a great many factually diverse kinds of property which have little in common to merit a uniform, peculiarly farorable tax treatment.

No doubt the reason for this silhouette scheme was the difficulty inherent in attempting to specify with precision just what types of transactions were to receive special consideration. This difficulty, in turn, sprang from the muddiness of the rationale for favored tax treatment of capital gains. Other than a few elliptical and superficial sentences scattered throughout congressional hearings and reports covering nearly thirty years, there is no comprehensive statement of whatever policies may constitute the raison d'etre of segregating capital gains and losses. Consequently, a court is confronted with the task of applying rules in relative ignorance of the reasons for them when asked to decide whether some novel set of facts produces capital gain or ordinary income. No wonder, then, that the courts have played with words like "business" and "customers" in a futile attempt to find answers which even a well-drafted statute would not yield if read in a vacuum. There has therefore been a tendency to let whatever passed through the coarse "trade or business" sieve fall into the "capital asset" bucket. Courts should reverse this approach and allow into the select class of capital assets only those assets which fall outside the scope of a broad "trade or business" clause.

However, the prospect for the future is not hopeless. At least one valiant, although unsuccessful, attempt has been made to interpret the capital gains provisions in accordance with the available evidence of congressional intent. In McAllister v. Commissioner, ${ }^{123}$ the Court of Appeals for the Second Circuit held that the income beneficiary of a testamentary trust would realize mere capital gain if the lump sum paid to her by the remainderman for the surrender of her rights under the trust exceeded the commuted value of those rights. ${ }^{120}$ In dissenting from this view, Judge Frank contended that the entire sum received by the income beneficiary should be taxed at progressive rates as ordinary income, principally on the ground that it constituted a mere "substitute for future payments which would be taxable as ordinary income, and resembles the advance payment of dividends, interest, or salaries." ${ }^{131}$ In support of his position, Judge Frank argued that the capital gains provisions should be construed in the light of the reason

128. Section 117 (a) (1) begins: "The term 'capital assets' means property held by the taxpayer (whether or not connected with his trade or business), but does not include stock in trade. ..."

129. 157 F.2d 235 (2d Cir. 1946), cert. denied, 330 U.S. 826 (1947).

130. Apparently INT. REv. CopE §113(a) (5) was thought to be applicable. See discussion in Section VI supra.

131. McAllister v. Commissioner, 157 F.2d 235, 239 (2d Cir. 1946). 
given for their enactment, i.e., Congress' belief that transfers of certain types of "capital investments" were being deterred by the taxation of any resultant profit at progressive rates. Applying this test to the case of the trust beneficiary who accepted a lump sum in lieu of her life interest, he concluded that it was "most unlikely that Congress intended by $\S 117$ to relieve such a taxpayer of ordinary tax burdens, to supply an incentive for the demolition of such a trust." 132

Although Judge Frank's opinion in the McAllister case is concerned with the "sale or exchange" aspect of the capital gains provisions, the same mode of analysis is equally applicable to the "trade or business" clause. By directing attention to the underlying reasons which supposedly justify the special treatment of capital gains, this approach would not only provide a safeguard against many of the resultant forms of abuse, ${ }^{133}$ but would also compel a continuing re-examination of those reasons. This might well furnish the impetus for legislative revision. A fresh approach is vitally needed in this area where so much thought has been devoted to the letter of the law and so little to its spirit.

132. Id. at 241 .

133. "If such an attitude should gain ground in the courts, it would be a mere matter of time before any scheme or device to convert ordinary income into capital gain would be doomed." Brodsky, Planning Business Transactions to Produce Capital Gains in Procendsings of the New York UnIVERSity Seventh ANnual Institute on Federal TAXation 302,319 (1949). 


\section{THE YALE LAW JOURNAL}

VOLUME 59

MAY, 1950

NUSIBER 6

EDITORIAL BOARD

DONALD F. TURNER

Edifor-in-Chief

Noraran ReDLICH

Executive Editor

ArNoLd Hoffaran

LLEWELLYN P. YOUNG

Comment Editors
Edward N. Bentuarin
Article and
Book Revicw Editor

Witrinzs D. Gnz:
Rrcinso F. IGL
Note Editors

GERALD D. Katcher

Case Editor

Afthur MI. Mfichaelso:

Managing Editor

Leo P. Arraboldi, Jr.

Curtis J. Berger

HeINZ F. Brauer

JoHN G. BURNETT

JoEL L. Carr

JaAies C. Cochrane

WALter G. FARR, JR.

HAROLD D. FIELD, JR.

Richard MI. FitzSnararons

DANIEL J. Freed

Stanley J. Friedaray

RICHARD N. GaRdNER

Bernabo H. Greenterg
Wimlians E. Hegarty

JAAIES D. HILEORN

JACK S. HOFFINGER

HENRY L. KrNG

ROBERT K. LIFTON

RoBERT P. LyoNs, III

BUREE MIARSHALL

HARROLD J. AfCCOAIAS

Patricta A. MíGowan

DONALD L. MEDLOCE

KURT W. MEICHTOR

Douglas S. Patarer

WIILIAXI R PERLIE
Jeroase Presto:t, Jr.

Jero:se H. REICII

Wirluas Dru Rogrrs

WEITAEY N. SEYzSOUR, JR.

MEdvin G. Sarsos

AFonkoE S. SLiger

Stuart W. Tanyer

Eurror E. Vose

ANDREW AS. WOOD

RAYaso:s H. You:G

JonN ZEADES

EDgar A.ZTigarast

Rrcharo A. Zumiga

MLARIE MÍcMLABoN

Business Secretary

Subscription price $\$ 5.50$ per year

This number, $\$ 1.00$

Canadĩan Subscription price $\$ 6.00$ per year; Forcign, $\$ 6.25$ per y'car;

for prices on other issues ingutire

The Yale Joumal Company, Box 401A Yale Station, New Havens, Connecticut 